\title{
MODEL PERANCANGAN SISTEM PEMESANAN TIKET BUS ANTAR KOTA ANTAR PROPINSI KHUSUS DI CABANG
}

\author{
Harijanto Pangestu \\ Information Systems Department, School of Information Systems, Binus University \\ Jl. K.H. Syahdan No. 9, Palmerah, Jakarta Barat 11480 \\ harijantopangestu@binus.ac.id
}

\begin{abstract}
At certain moments, especially on national holiday transportation users greatly increase. The manual ticket booking system of inter-city buses is not very effective and efficient as indicated that it takes long time to book tickets and find information about ticket availability for a specific purpose on a certain day. Besides, inaccuracies often happen on synchronizing ticket availability with seat availability. Due to those problems, it needs to be made a model of ticketing information system of inter-city buses. The initial phase focused on booking tickets at a branch office. The next stage of development is integrating the information system of all branch offices to the central office. The purpose of this paper is to create a model of the system design if intercity bus ticket reservation in inter-provincial branches can provide convenience for the branch to book tickets booked by customers. The methodology used in this research is a preliminary study by library research, followed by analysis on running systems through survey findings, then identification of information needs. From the results of this study it is found that a more specific design and implementation are expected to be made so as to provide more benefits to its users. The results of this study can be further developed and integrated with the central office.
\end{abstract}

Keywords: application, bookings, bus tickets, inter-city, inter-provincial

\begin{abstract}
ABSTRAK
Pada saat-saat tertentu terutama hari-hari libur nasional peminat transportasi sangat meningkat. Sistem informasi pemesanan tiket bus antar kota antar propinsi yang masih manual sangat tidak efektif dan efisien yang ditunjukkan dengan lamanya pelayanan kepada calon penumpang yang memesan tiket, lamanya informasi ketersediaan tiket untuk tujuan tertentu pada hari tertentu, ketidakakuratan informasi ketersediaan tiket dengan ketersediaan tempat duduk akan menghambat kemajuan bisnis transportasi bus antar kota antar propinsi. Karena itu perlu dibuat suatu model sistem informasi pemesanan tiket antar kota antar propinsi. Tahap awal difokuskan pada pemesanan tiket untuk di cabang. Tahap berikutnya dikembangkan sistem informasi yang lebih menyeluruh untuk cabang yang pada akhirnya dikembangkan sistem informasi terpadu antar kota antar propinsi yang terintegrasi dengan kantor pusat. Tujuan dari penulisan ini adalah membuat model perancangan sistem pemesanan tiket bus antar kota antar propinsi khusus di cabang yang dapat memberikan kemudahan bagi cabang untuk melakukan pemesanan tiket yang dipesan oleh pelanggan. Metodologi penelitian yang digunakan adalah studi awal dengan melakukan studi kepustakaan, metode analisis dengan survei pada sistem yang berjalan, analisis terhadap temuan survei, identifikasi kebutuhan informasi. Hasil dari penulisan ini diharapkan dapat dibuat rancangan yang lebih spesifik serta implementasi sehingga memberikan manfaat lebih dalam penggunaannya. Hasil penulisan ini dapat lebih dikembangkan dan diintegrasikan dengan kantor pusat.
\end{abstract}

Kata kunci: aplikasi, pemesanan, tiket bus, antar kota, antar propinsi 


\section{PENDAHULUAN}

Transportasi bus antar kota antar propinsi sangat dibutuhkan oleh masyarakat yang anggota keluarganya tinggal di lain kota atau lain propinsi. Pada saat-saat tertentu terutama hari-hari libur bahkan terutama hari-hari libur nasional keberadaan transportasi bus antar kota antar propinsi sangat meningkat peminatnya. Sistem informasi pemesanan tiket antar kota antar propinsi yang masih manual tentu saja sangat tidak efektif dan efisien terutama saat-saat menjelang hari-hari yang telah disebutkan di atas. Lamanya pelayanan kepada calon penumpang yang memesan tiket, lamanya informasi tentang ketersediaan tiket untuk tujuan tertentu pada hari tertentu, ketidak akuratan informasi ketersediaan tiket dengan ketersediaan tempat duduk tentu saja akan menghambat kemajuan bisnis transportasi bus antar kota antar propinsi tersebut.

Karena itu perlu dibuat suatu model sistem informasi pemesanan tiket antar kota antar propinsi. Pada tahap awal ini hanya difokuskan pada pemesanan tiket untuk di cabang saja. Pada tahap berikutnya akan dikembangkan sistem informasi yang lebih menyeluruh untuk cabang tersebut yang pada akhirnya akan dikembangkan sistem informasi terpadu antar kota antar propinsi yang terintegrasi dengan kantor pusat.

Sistem informasi mengumpulkan, memproses, menyimpan, menganalisis, dan menyebarkan informasi untuk tujuan tertentu. Sistem informasi tidak harus terkomputerisasi, walaupun kebanyakan memang terkomputerisasi. Sistem informasi berbasis komputer adalah sistem informasi yang menggunakan teknologi komputer untuk melakukan beberapa atau seluruh pekerjaan yang diberikan (Turban, et al., 2006).

Menurut Undang-undang no. 22 tahun 2009 tentang Lalu Lintas dan Angkutan Jalan bahwa angkutan adalah perpindahan orang dan/atau barang dari satu tempat ke tempat lain dengan menggunakan kendaraan di Ruang Lalu Lintas Jalan. Kendaraan Bermotor Umum adalah setiap Kendaraan yang digunakan untuk angkutan barang dan/atau orang dengan dipungut bayaran. Terminal adalah pangkalan Kendaraan Bermotor Umum yang digunakan untuk mengatur kedatangan dan keberangkatan, menaikkan dan menurunkan orang dan/atau barang, serta perpindahan moda angkutan. Halte adalah tempat pemberhentian Kendaraan Bermotor Umum untuk menaikkan dan menurunkan penumpang.

Ruang lingkup penelitian dibatasi pada pembuatan model perancangan sistem informasi pemesanan tiket bus antar kota antar propinsi khusus di cabang saja. Cabang yang dimaksud adalah cabang dari perusahaan yang berada dalam suatu kota di propinsi tertentu. Model perancangan sistem informasi ini tidak termasuk ke seluruhan sistem di cabang tersebut. Keseluruhan sistem merupakan rencana pengembangan penelitian untuk tahap selanjutnya. Tahap keseluruhan dari pengembangan penelitian ini adalah membuat model yang akan mengintegrasikan sistem informasi di cabang dengan sistem informasi di pusat sehingga menjadi sistem informasi yang terintegrasi secara keseluruhan.

Tujuan dari penulisan ini adalah menganalisis kebutuhan-kebutuhan informasi dalam pemesanan tiket antar kota antar propinsi dan membuat model perancangan sistem informasi pemesanan tiket antar kota antar propinsi sehingga dapat dikembangkan pada tahap penelitian berikutnya.

Manfaat yang diharapkan adalah dengan dibuatnya suatu model perancangan sistem informasi pemesanan tiket antar kota antar propinsi maka dapat dirancang suatu sistem informasi yang mudah untuk dibangun dan diterapkan sehingga dapat mempermudah pemesanan tiket khususnya pemesanan tiket di cabang. Dengan dibuatnya suatu model perancangan sistem informasi pemesanan tiket antar kota antar propinsi ini maka diharapkan akan dikembangkan model perancangan sistem informasi 
transportasi khusus di cabang secara keseluruhan dan pada akhirnya akan dikembangkan suatu model perancangan sistem informasi yang terpadu antar cabang dengan kantor pusat.

\section{METODE}

Metodologi penelitian yang digunakan adalah studi awal dengan melakukan studi kepustakaan, metode analisis dengan survei pada sistem yang berjalan, analisis terhadap temuan survei, identifikasi kebutuhan informasi. Dilanjutkan dengan perancangan menggunakan use case diagram, class diagram, dan sequence diagram.

\section{HASIL DAN PEMBAHASAN}

Di bawah ini adalah use case diagram sistem informasi reservasi dan penjualan tiket bus yang dibuat (Gambar 1). Selanjutnya, di bawah ini adalah class diagram sistem informasi reservasi dan penjualan tiket bus yang dibuat (Gambar 2). Gambar-gambar di bawah ini adalah beberapa sequence diagram yang dibuat (Gambar 3 - 7). Gambar 11 di bawah ini adalah tampilan isian pencarian jadwal perjalanan sistem informasi reservasi dan penjualan tiket bus yang telah dirancang. Hasil Cetakan Tiket dapat dilihat pada Gambar 12. Terakhir adalah sebagian tampilan reservasi dan penjualan tiket (Gambar 13).

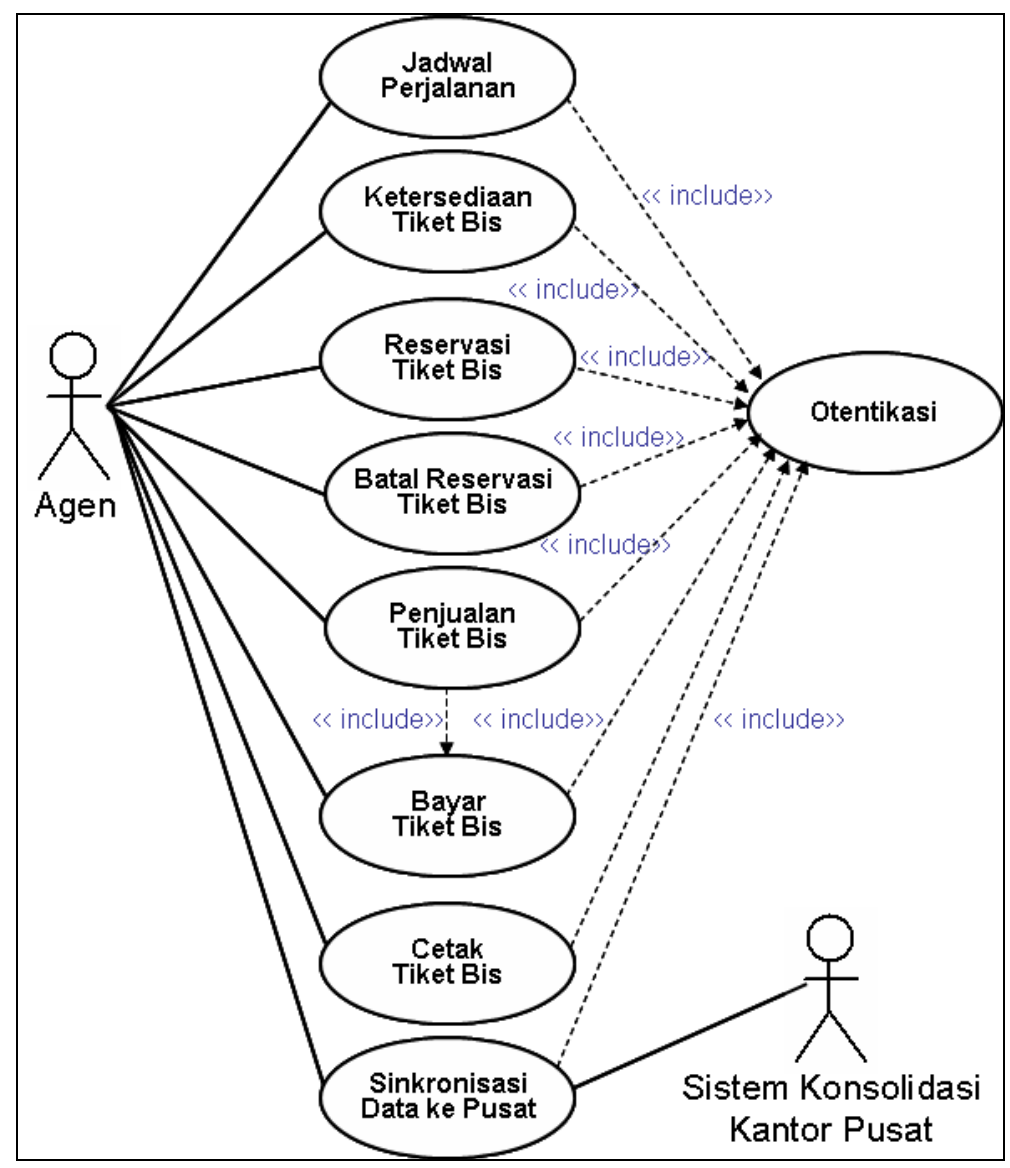

Gambar 1 Use case diagram 


\begin{tabular}{|c|c|c|}
\hline \begin{tabular}{|l|} 
Use Case Name \\
\end{tabular} & \multicolumn{2}{|l|}{ Jadwal Perjalanan } \\
\hline Use Case-ID & \multicolumn{2}{|l|}{ UC-01 } \\
\hline Actors & \multicolumn{2}{|l|}{ Agen } \\
\hline Purpose & \multicolumn{2}{|c|}{ Agen dapat melihat jadwal perjalanan bis. } \\
\hline Overview & \multicolumn{2}{|c|}{$\begin{array}{l}\text { Agen dapat melihat jadwal perjalanan bis berdasarkan kota asal, kota tujuan, untuk } \\
\text { propinsi yang sama maupun yang berbeda beserta tanggal berangkat, jam berangkat, } \\
\text { jam tiba, dan kelas bis. }\end{array}$} \\
\hline Type & \multicolumn{2}{|l|}{ Essential. } \\
\hline Preconditions & \multicolumn{2}{|c|}{ Agen sudah ter-otentikasi oleh sistem. } \\
\hline Postconditions & \multicolumn{2}{|c|}{$\begin{array}{l}\text { Agen dapat melihat jadwal perjalanan bis kemudian agen dapat melihat ketersediaan } \\
\text { tiket bis. }\end{array}$} \\
\hline \multicolumn{3}{|c|}{ Flow of Events } \\
\hline & Actor Action & System Response \\
\hline \multicolumn{2}{|c|}{$\begin{array}{l}\text { 1. Use Case ini dimulai ketika Agen memilih } \\
\text { jadwal perjalanan. }\end{array}$} & $\begin{array}{l}\text { 2. Sistem menampilkan daftar isian pencarian jadwal } \\
\text { perjalanan. }\end{array}$ \\
\hline \multicolumn{2}{|c|}{$\begin{array}{l}\text { 3. Agen memasukkan isian pencarian jadwal } \\
\text { perjalanan. }\end{array}$} & $\begin{array}{l}\text { 4. Sistem menampilkan jadwal perjalanan. } \\
\text { A1. Jadwal perjalanan yang dicari tidak ada. }\end{array}$ \\
\hline \multicolumn{2}{|c|}{$\begin{array}{l}\text { 5. Use Case ini berakhir ketika Agen selesai } \\
\text { mencari dan melihat jadwal perjalanan yang } \\
\text { diinginkannya kemudian memilih exit. }\end{array}$} & \\
\hline \multicolumn{3}{|c|}{ Alternative Flow of Events } \\
\hline \multicolumn{3}{|c|}{$\begin{array}{l}\text { A1: Jadwal perjalanan yang dicari tidak ada. } \\
\text { 1. Sistem menampilkan pesan bahwa jadwal perjalan yang dicari tidak ada. } \\
\text { 2. Agen mengkonfirmasi pesan tersebut } \\
\text { 3. Aliran kembali ke aliran utama, langkah ke: } 3\end{array}$} \\
\hline
\end{tabular}

\begin{tabular}{|c|c|c|}
\hline $\begin{array}{l}\text { Use Case } \\
\text { Name }\end{array}$ & \multicolumn{2}{|l|}{ Ketersediaan Tiket BIS } \\
\hline Use Case-ID & \multicolumn{2}{|l|}{ UC-02 } \\
\hline Actors & \multicolumn{2}{|l|}{ Agen } \\
\hline Purpose & \multicolumn{2}{|c|}{ Agen dapat melihat ketersediaan tiket bis sesuai dengan jadwal perjalanan bis. } \\
\hline Overview & \multicolumn{2}{|c|}{$\begin{array}{l}\text { Agen dapat melihat ketersediaan tiket bis sesuai dengan jadwal perjalanan bis } \\
\text { berdasarkan kota asal menuju kota tujuan untuk propinsi yang sama maupun yang } \\
\text { berbeda beserta tanggal berangkat, jam berangkat, jam tiba, dan kelas bis. }\end{array}$} \\
\hline Type & \multicolumn{2}{|c|}{ Essential. } \\
\hline Preconditions & \multicolumn{2}{|c|}{ Agen sudah ter-otentikasi oleh sistem. } \\
\hline Postconditions & \multicolumn{2}{|c|}{$\begin{array}{l}\text { Agen dapat melihat ketersediaan tiket bis sesuai jadwal perjalanan bis kemudian agen } \\
\text { dapat mereservasi tiket. }\end{array}$} \\
\hline \multicolumn{3}{|c|}{ Flow of Events } \\
\hline & Actor Action & System Response \\
\hline \multicolumn{3}{|c|}{\begin{tabular}{|l|l} 
1. Use Case ini dimulai ketika Agen memilih & $\begin{array}{l}\text { 2. Sistem menampilkan daftar isian pencarian jadwal } \\
\text { perjalanan. }\end{array}$ \\
Ketersediaan Tiket. &
\end{tabular}} \\
\hline \multicolumn{2}{|c|}{$\begin{array}{l}\text { 3. Agen memasukkan isian pencarian jadwal } \\
\text { perjalanan. }\end{array}$} & $\begin{array}{l}\text { 4. Sistem menampilkan ketersediaan tiket sesuai jadwal } \\
\text { perjalanan. } \\
\text { A1. Jadwal perjalanan yang dicari tidak ada. } \\
\text { A2. Tiket sudah habis }\end{array}$ \\
\hline $\begin{array}{l}\text { 5. Use Case ini } \\
\text { melihat ketersec } \\
\text { perjalanan yang } \\
\text { memilih exit. } \\
\end{array}$ & $\begin{array}{l}\text { berakhir ketika Agen selesai } \\
\text { diaan tiket bis sesuai jadwal } \\
\text { g diinginkannya dan agen }\end{array}$ & \\
\hline
\end{tabular}




\section{Alternative Flow of Events}

A1: Jadwal perjalanan yang dicari tidak ada.

1. Sistem menampilkan pesan bahwa jadwal perjalan yang dicari tidak ada.

2. Agen mengkonfirmasi pesan tersebut

3. Aliran kembali ke aliran utama, langkah ke: 3

A2: Tiket sudah habis.

1. Sistem menampilkan pesan bahwa Tiket sudah habis.

2. Agen mengkonfirmasi pesan tersebut

3. Aliran kembali ke aliran utama, langkah ke: 3

\begin{tabular}{|c|c|c|}
\hline $\begin{array}{l}\text { Use Case } \\
\text { Name }\end{array}$ & \multicolumn{2}{|l|}{ Reservasi Tiket BIS } \\
\hline Use Case-ID & \multicolumn{2}{|l|}{ UC-03 } \\
\hline Actors & \multicolumn{2}{|l|}{ Agen } \\
\hline Purpose & \multicolumn{2}{|c|}{ Agen dapat melihat mereservasi tiket bis sesuai dengan ketersediaan tiket. } \\
\hline Overview & \multicolumn{2}{|c|}{ Agen dapat melihat mereservasi tiket bis sesuai dengan ketersediaan tiket. } \\
\hline Type & \multicolumn{2}{|c|}{ Essential. } \\
\hline Preconditions & \multicolumn{2}{|c|}{ Agen sudah ter-otentikasi oleh sistem. } \\
\hline Postconditions & \multicolumn{2}{|c|}{$\begin{array}{l}\text { Agen dapat melihat mereservasi tiket bis sesuai dengan ketersediaan tiket kemudian } \\
\text { Agen dapat membayar tiket. }\end{array}$} \\
\hline \multicolumn{3}{|c|}{ Flow of Events } \\
\hline & Actor Action & System Response \\
\hline $\begin{array}{l}\text { 1. Use Case ini } \\
\text { Reservasi Tike }\end{array}$ & $\begin{array}{l}\text { dimulai ketika Agen memilih } \\
\text { t. }\end{array}$ & $\begin{array}{l}\text { 2. Sistem menampilkan daftar isian pencarian jadwal } \\
\text { perjalanan. }\end{array}$ \\
\hline $\begin{array}{l}\text { 3. Agen memas } \\
\text { perjalanan. }\end{array}$ & sukkan isian pencarian jadwal & $\begin{array}{l}\text { 4. Sistem menampilkan ketersediaan tiket sesuai jadwal } \\
\text { perjalanan dan denah nomor kursi bis. } \\
\text { A1. Jadwal perjalanan yang dicari tidak ada. } \\
\text { A2. Tiket sudah habis }\end{array}$ \\
\hline 5. Agen memil & ih no.kursi bis. & $\begin{array}{l}\text { 6. Sistem menampilkan informasi pemesanan no.kursi } \\
\text { bis yang dipesan Agen. }\end{array}$ \\
\hline $\begin{array}{l}\text { 7. Agen mengk } \\
\text { tersebut. } \\
\end{array}$ & onfirmasi pemesan no.kursi & $\begin{array}{l}\text { 8. Sistem menampilkan pesan no.kursi telah berhasil } \\
\text { dipesan. }\end{array}$ \\
\hline $\begin{array}{l}\text { 9. Use Case ini } \\
\text { memesan tiket }\end{array}$ & $\begin{array}{l}\text { berakhir ketika Agen selesai } \\
\text { bis dan agen memilih exit. }\end{array}$ & \\
\hline \multicolumn{3}{|c|}{ Alternative Flow of Events } \\
\hline \multicolumn{3}{|c|}{$\begin{array}{l}\text { A1: Jadwal perjalanan yang dicari tidak ada. } \\
\text { 1. Sistem menampilkan pesan bahwa jadwal perjalan yang dicari tidak ada. } \\
\text { 2. Agen mengkonfirmasi pesan tersebut } \\
\text { 3. Aliran kembali ke aliran utama, langkah ke: } 3 \\
\text { A2: Tiket sudah habis. } \\
\text { 1. Sistem menampilkan pesan bahwa Tiket sudah habis. } \\
\text { 2. Agen mengkonfirmasi pesan tersebut } \\
\text { 3. Aliran kembali ke aliran utama, langkah ke: } 3 \\
\end{array}$} \\
\hline
\end{tabular}

\begin{tabular}{|l|l|}
\hline $\begin{array}{l}\text { Use Case } \\
\text { Name }\end{array}$ & Batal Reservasi Tiket BIS \\
\hline Use Case-ID & UC-04 \\
\hline Actors & Agen \\
\hline Purpose & Agen dapat membatalkan reservasi tiket bis. \\
\hline Overview & Agen dapat membatalkan reservasi tiket bis. \\
\hline
\end{tabular}




\begin{tabular}{|l|l|}
\hline Type & Essential. \\
\hline Preconditions & Agen sudah ter-otentikasi oleh sistem. \\
\hline Postconditions & Agen dapat membatalkan reservasi tiket bis. \\
\hline \multicolumn{2}{|c|}{ Alow of Events } \\
\hline \multicolumn{1}{|c|}{ Actor Action } & \multicolumn{1}{c|}{ System Response } \\
\hline $\begin{array}{l}\text { 1. Use Case ini dimulai ketika Agen memilih } \\
\text { Batal Reservasi Tiket. }\end{array}$ & $\begin{array}{l}\text { 2. Sistem menampilkan daftar tiket yang telah } \\
\text { direservasi oleh Agen tersebut. }\end{array}$ \\
\hline $\begin{array}{l}\text { 3. Agen memilih tiket yang akan dibatalkan } \\
\text { reservasinya. }\end{array}$ & $\begin{array}{l}\text { 4. Sistem menampilkan informasi tiket yang akan } \\
\text { dibatalkan reservasinya. }\end{array}$ \\
\hline $\begin{array}{l}\text { 5. Agen mengkonfirmasi pembatalan no.tiket } \\
\text { bis tersebut. }\end{array}$ & $\begin{array}{l}\text { 6. Sistem menampilkan bahwa tiket bis telah dibatalkan } \\
\text { reservasinya. }\end{array}$ \\
\hline $\begin{array}{l}\text { 7. Use Case ini berakhir ketika Agen selesai } \\
\text { membatalkan tiket yang telah direservasinya } \\
\text { dan agen memilih exit. }\end{array}$ & \multicolumn{1}{|c|}{ Alternative Flow of Events } \\
\hline \multicolumn{2}{|c|}{ - } \\
\hline
\end{tabular}

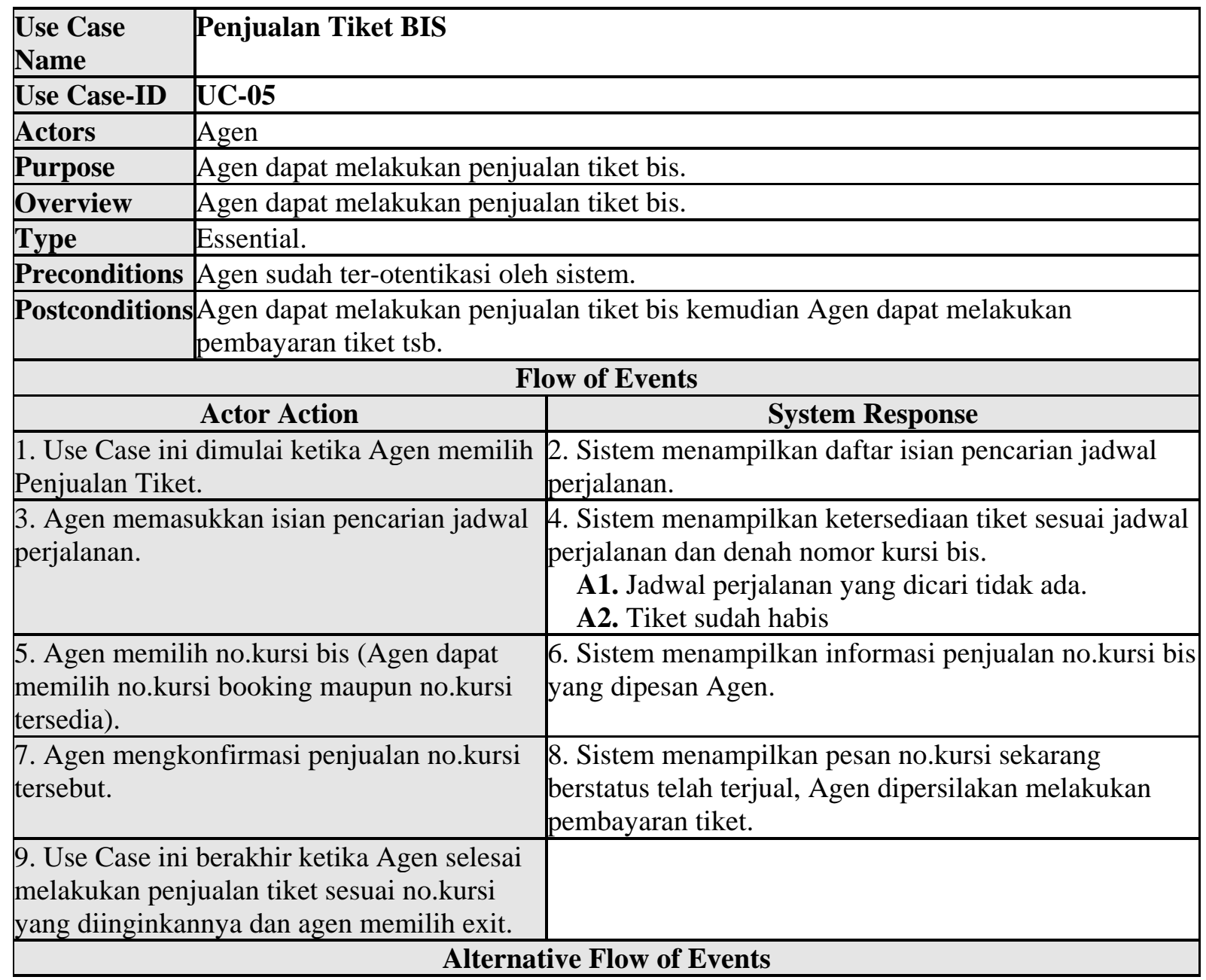


A1: Jadwal perjalanan yang dicari tidak ada.

1. Sistem menampilkan pesan bahwa jadwal perjalan yang dicari tidak ada.

2. Agen mengkonfirmasi pesan tersebut

3. Aliran kembali ke aliran utama, langkah ke: 3

A2: Tiket sudah habis.

1. Sistem menampilkan pesan bahwa Tiket sudah habis.

2. Agen mengkonfirmasi pesan tersebut

3. Aliran kembali ke aliran utama, langkah ke: 3

\begin{tabular}{|c|c|c|}
\hline \begin{tabular}{|l|} 
Use Case \\
Name
\end{tabular} & \multicolumn{2}{|l|}{ Bayar Tiket BIS } \\
\hline Use Case-ID & \multicolumn{2}{|l|}{ UC-06 } \\
\hline Actors & \multicolumn{2}{|l|}{ Agen } \\
\hline Purpose & \multicolumn{2}{|c|}{ Agen dapat melakukan pembayaran tiket bis. } \\
\hline Overview & \multicolumn{2}{|c|}{ Agen dapat melakukan pembayaran tiket bis. } \\
\hline Type & \multicolumn{2}{|c|}{ Essential. } \\
\hline Preconditions & \multicolumn{2}{|c|}{ Agen sudah ter-otentikasi oleh sistem. } \\
\hline Postconditions & \multicolumn{2}{|c|}{$\begin{array}{l}\text { Agen dapat melakukan pembayaran tiket bis kemudian Agen dapat mencetak tiket } \\
\text { tersebut. }\end{array}$} \\
\hline \multicolumn{3}{|c|}{ Flow of Events } \\
\hline & Actor Action & System Response \\
\hline $\begin{array}{l}\text { 1. Use Case ini } \\
\text { Bayar Tiket. }\end{array}$ & dimulai ketika Agen memilih & $\begin{array}{l}\text { 2. Sistem menampilkan daftar tiket yang telah dijual } \\
\text { dan belum lunas. }\end{array}$ \\
\hline 3. Agen memilil & ih tiket yang akan dibayarnya. & $\begin{array}{l}\text { 4. Sistem menampilkan informasi tiket yang akan } \\
\text { dibayarnya dan jumlah pembayaran. } \\
\text { 5. Sistem menampilkan isian tipe pembayaran. }\end{array}$ \\
\hline 6. Agen memast & sukkan tipe pembayaran. & $\begin{array}{l}\text { 6. Sistem menampilkan isian data pembayaran sesuai } \\
\text { dengan tipe pembayaran. }\end{array}$ \\
\hline 7. Agen memast & sukkan data pembayaran. & $\begin{array}{l}\text { 8. Sistem menampilkan pesan jumlah, data pembayaran } \\
\text { serta daftar tiket yang akan dibayar. }\end{array}$ \\
\hline 9. Agen mengko & onfirmasi pembayaran. & $\begin{array}{l}\text { 10. Sistem menampilkan pesan pembayaran telah } \\
\text { terlaksana. }\end{array}$ \\
\hline $\begin{array}{l}\text { 11. Use Case ini } \\
\text { melakukan peml } \\
\text { tipe pembayaran } \\
\text { memilih exit. }\end{array}$ & $\begin{array}{l}\text { ii berakhir ketika Agen selesai } \\
\text { abayaran tiket sesuai dengan } \\
\text { in yang diinginkannya dan agen }\end{array}$ & \\
\hline \multicolumn{3}{|c|}{ Alternative Flow of Events } \\
\hline
\end{tabular}

\begin{tabular}{|l|l|}
\hline $\begin{array}{l}\text { Use Case } \\
\text { Name }\end{array}$ & Cetak Tiket BIS \\
\hline Use Case-ID & UC-07 \\
\hline Actors & Agen \\
\hline Purpose & Agen dapat melakukan cetak tiket bis yang telah dibayarnya. \\
\hline Overview & Agen dapat melakukan cetak tiket bis yang telah dibayarnya. \\
\hline Type & Essential. \\
\hline Preconditions & $\begin{array}{l}\text { Agen sudah ter-otentikasi oleh sistem dan telah melakukan pembayaran tiket yang } \\
\text { akan dicetaknya. }\end{array}$ \\
\hline Postconditions & Agen mendapat cetakan tiket bis yang telah dibayarnya. \\
\hline \multicolumn{2}{|c|}{ Flow of Events } \\
\hline
\end{tabular}




\begin{tabular}{|l|l|}
\hline \multicolumn{1}{|c|}{ Actor Action } & \multicolumn{1}{c|}{ System Response } \\
\hline $\begin{array}{l}\text { 1. Use Case ini dimulai ketika Agen memilih } \\
\text { Cetak Tiket. }\end{array}$ & $\begin{array}{l}\text { 2. Sistem menampilkan daftar tiket yang telah dibayar } \\
\text { dan belum dicetak. }\end{array}$ \\
\hline 3. Agen memilih tiket yang akan dicetaknya. & $\begin{array}{l}\text { 4. Sistem menampilkan informasi tiket yang akan } \\
\text { dicetak. }\end{array}$ \\
\hline 5. Agen mengkonfirmasi pencetakan tiket. & $\begin{array}{l}\text { 6. Sistem menampilkan pesan pencetakan sedang } \\
\text { dilakukan. } \\
\text { 7. Sistem menampilkan pesan selesai melakukan } \\
\text { pencetakan. }\end{array}$ \\
\hline $\begin{array}{l}\text { 8. Use Case ini berakhir ketika Agen selesai } \\
\text { melakukan pencetakan tiket yang telah } \\
\text { dibayarnya dan dan Agen memilih exit. }\end{array}$ & \multicolumn{2}{|c|}{ Alternative Flow of Events } \\
\hline \multicolumn{2}{|c|}{ - } \\
\hline \multicolumn{2}{|c|}{} \\
\hline
\end{tabular}

\begin{tabular}{|c|c|c|}
\hline \begin{tabular}{|l|} 
Use Case \\
Name
\end{tabular} & \multicolumn{2}{|l|}{ Sinkronisasi Data } \\
\hline Use Case-ID & \multicolumn{2}{|l|}{ UC-08 } \\
\hline Actors & \multicolumn{2}{|l|}{ Agen } \\
\hline Purpose & \multicolumn{2}{|c|}{ Agen dapat melakukan sinkronisasi data dengan pusat. } \\
\hline Overview & \multicolumn{2}{|c|}{$\begin{array}{l}\text { Agen dapat melakukan sinkronisasi data dengan pusat. Pusat telah memverifikasi data } \\
\text { yang berhubungan dengan agen. Agen mendapat backup-database khusus } \\
\text { keagenannya yang akan berguna bila terjadi sesuatu terhadap keseluruhan sistem } \\
\text { pusat. }\end{array}$} \\
\hline Type & \multicolumn{2}{|c|}{ Essential. } \\
\hline Preconditions & \multicolumn{2}{|c|}{ Agen sudah ter-otentikasi oleh sistem. } \\
\hline Postconditions & \multicolumn{2}{|c|}{$\begin{array}{l}\text { Agen dapat melakukan sinkronisasi data dengan pusat. Pusat telah memverifikasi } \\
\text { data-data keagenannya dan Agen telah mendapat backup-database contigency. }\end{array}$} \\
\hline \multicolumn{3}{|c|}{ Flow of Events } \\
\hline \multicolumn{2}{|r|}{ Actor Action } & System Response \\
\hline \multicolumn{2}{|c|}{$\begin{array}{l}\text { 1. Use Case ini dimulai ketika Agen memilih } \\
\text { Sinkronisasi Data. }\end{array}$} & $\begin{array}{l}\text { 2. Sistem menampilkan informasi terakhir sinkronisasi } \\
\text { data. } \\
\text { 3. Sistem menampilkan konfirmasi sinkronisasi data. }\end{array}$ \\
\hline \multicolumn{2}{|c|}{ 4. Agen mengkonfirmasi sinkronisasi data. } & $\begin{array}{l}\text { 5. Sistem menampilkan sedang sinkronisasi data. } \\
\text { 6. Sistem menampilkan pesan selesai melakukan } \\
\text { sinkronisasi data. } \\
\text { E1. Koneksi Jaringan terputus. }\end{array}$ \\
\hline \multicolumn{3}{|c|}{\begin{tabular}{|l|l} 
7. Use Case ini berakhir ketika Agen selesai & \\
melakukan sinkronisasi data dengan pusat. & \\
\end{tabular}} \\
\hline \multicolumn{3}{|c|}{ Alternative Flow of Events } \\
\hline \\
\hline \multicolumn{3}{|c|}{ Error Flow of Events } \\
\hline $\begin{array}{l}\text { E1: Koneksi Jar } \\
\text { 1. Sistem menar } \\
\text { 2. Agen mengkc } \\
\text { 3. Aliran kemba }\end{array}$ & $\begin{array}{l}\text { ringan terputus. } \\
\text { ampilkan error koneksi jaringan } \\
\text { ronfirmasi pesan tersebut } \\
\text { ali ke aliran utama, langkah ke }\end{array}$ & n terputus. \\
\hline
\end{tabular}




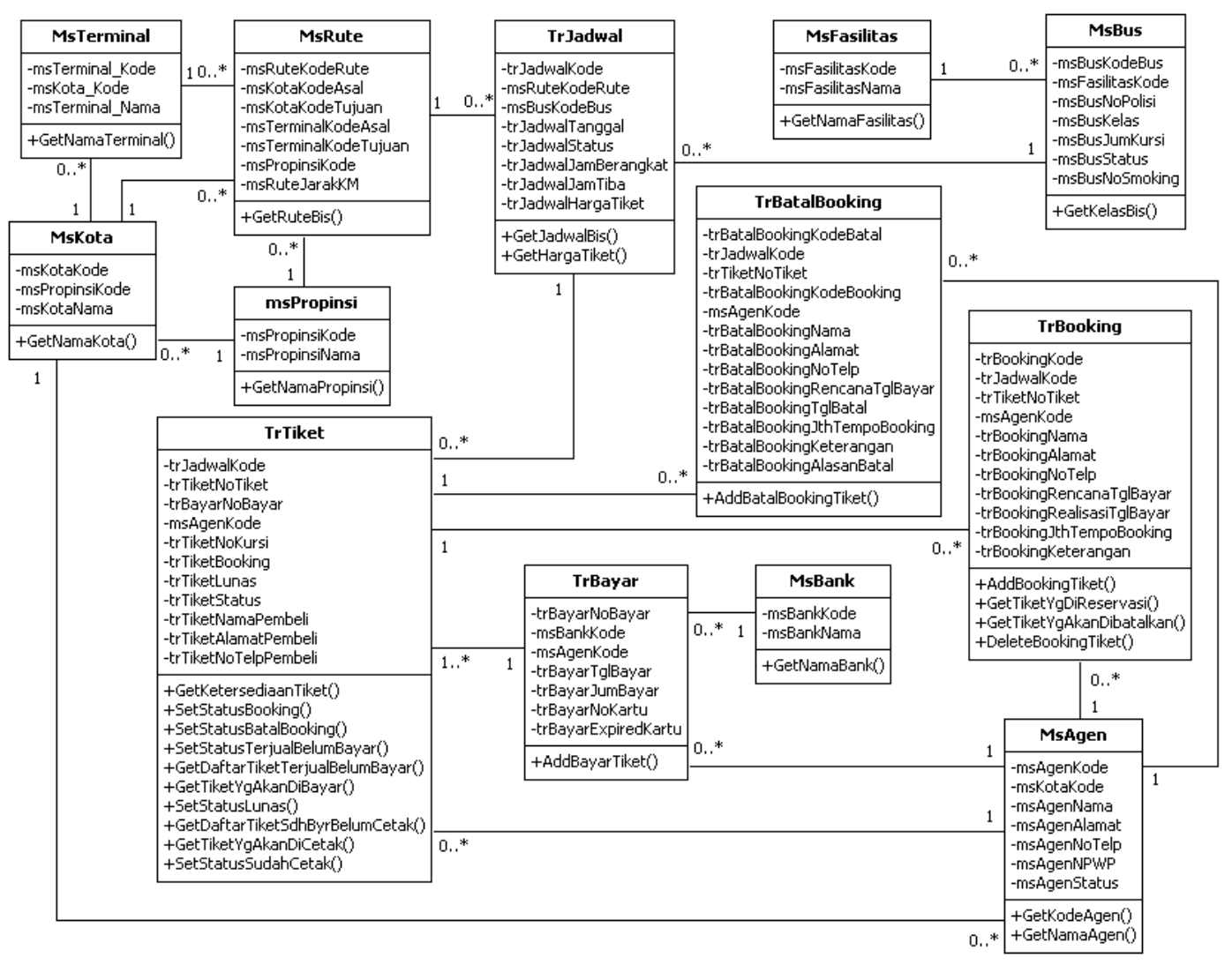

Gambar 2 Class diagram

\section{Sequence Diagram Untuk Use Case Jadwal Perjalanan}

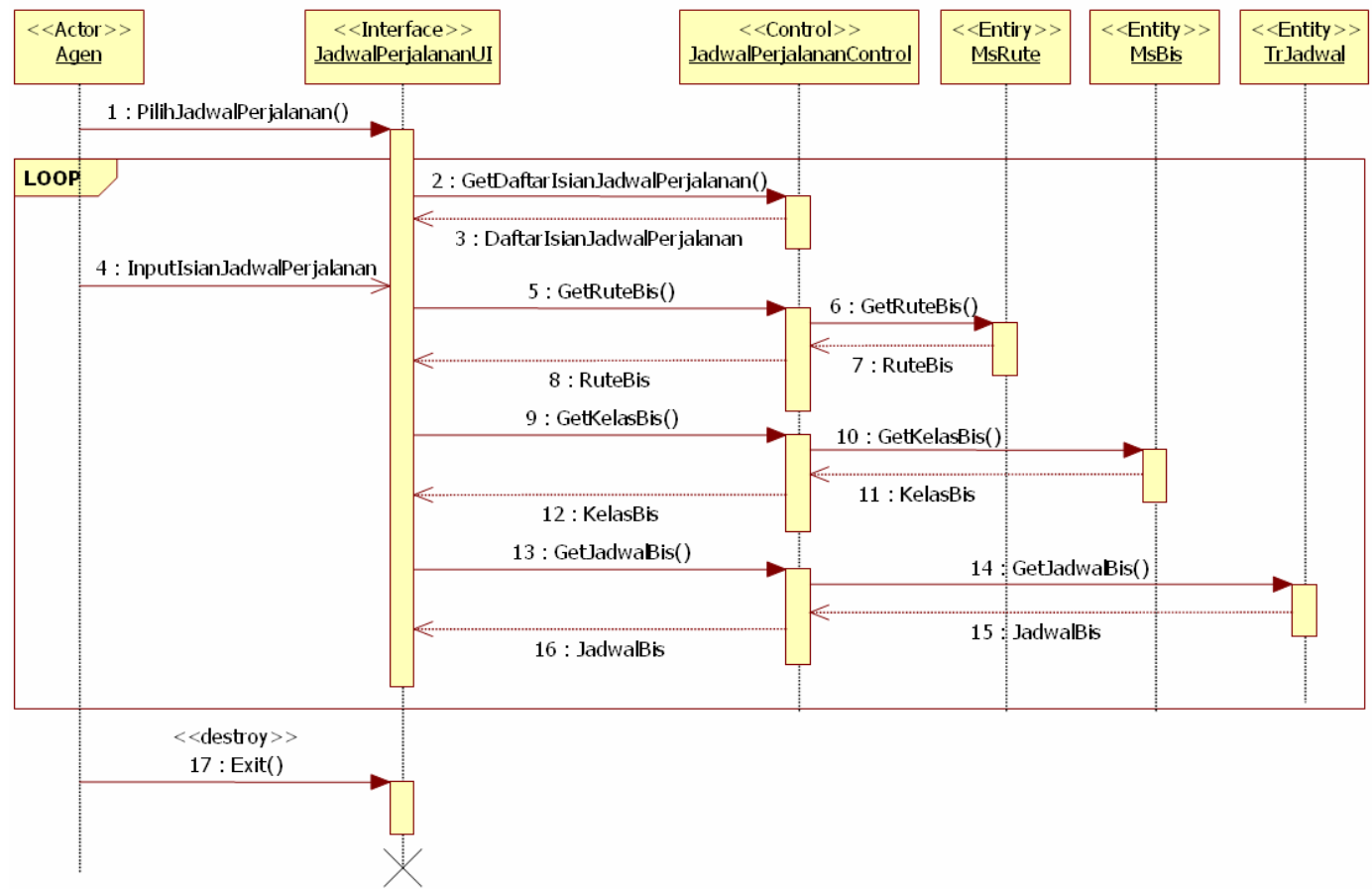

Gambar 3 Sequence diagram untuk use case jadwal perjalanan 
Sequence Diagram Untuk Use Case Ketersediaan Tiket

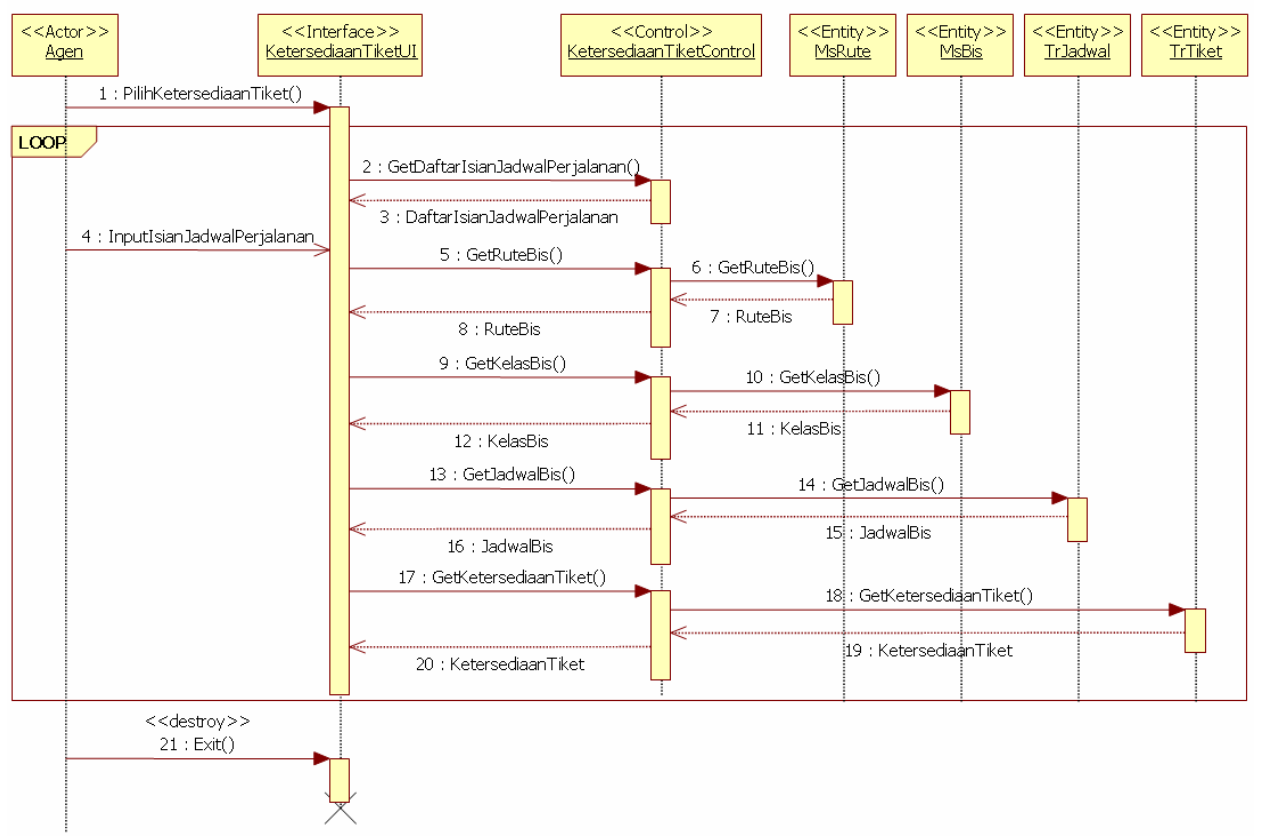

Gambar 4 Sequence diagram untuk use case ketersediaan tiket

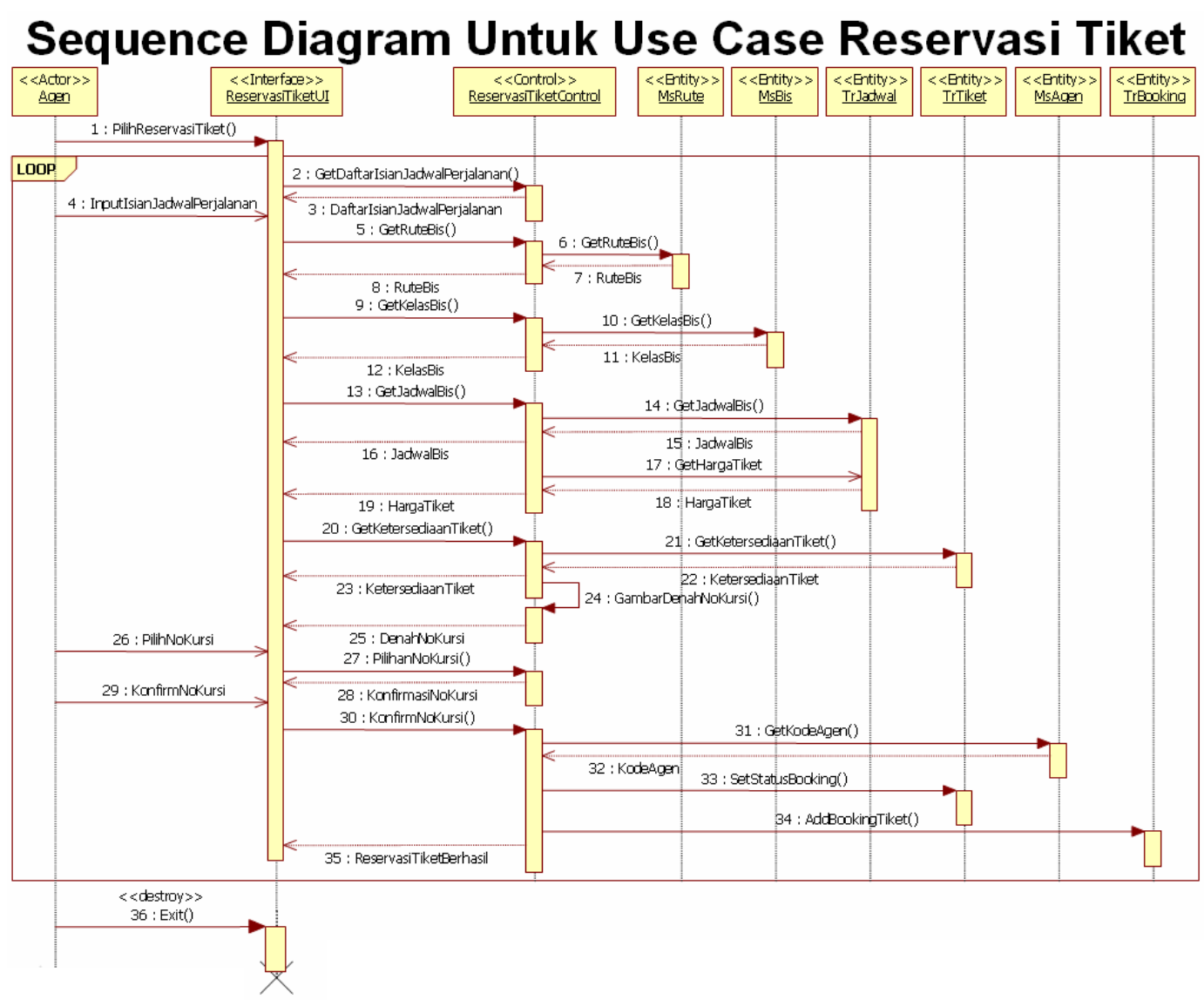

Gambar 5 Sequence diagram untuk use case reservasi tiket 


\section{Sequence Diagram Untuk Use Case Batal Reservasi Tiket}

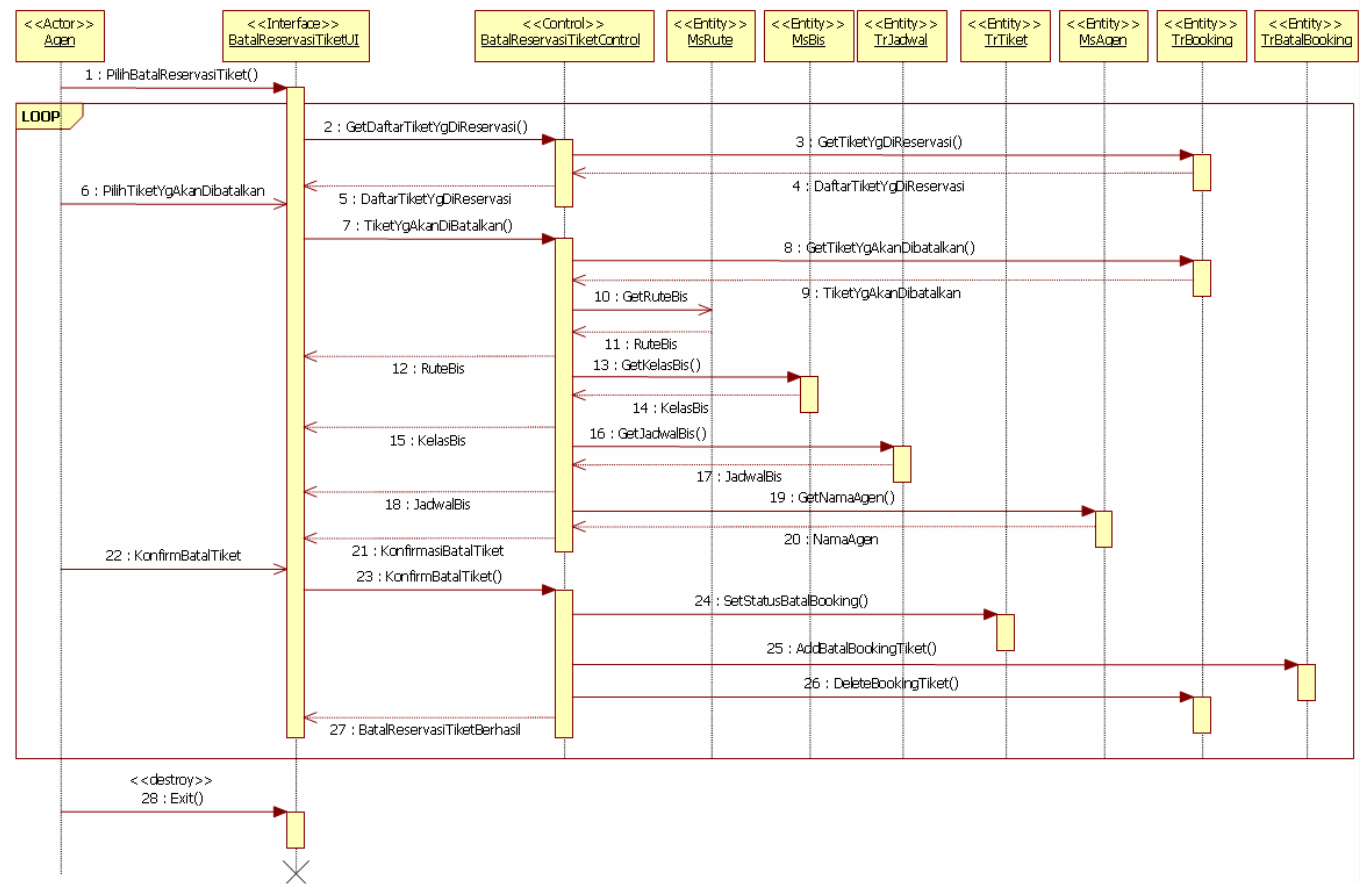

Gambar 6 Sequence diagram untuk use case batal reservasi tiket

\section{Sequence Diagram Untuk Use Case Penjualan Tiket}

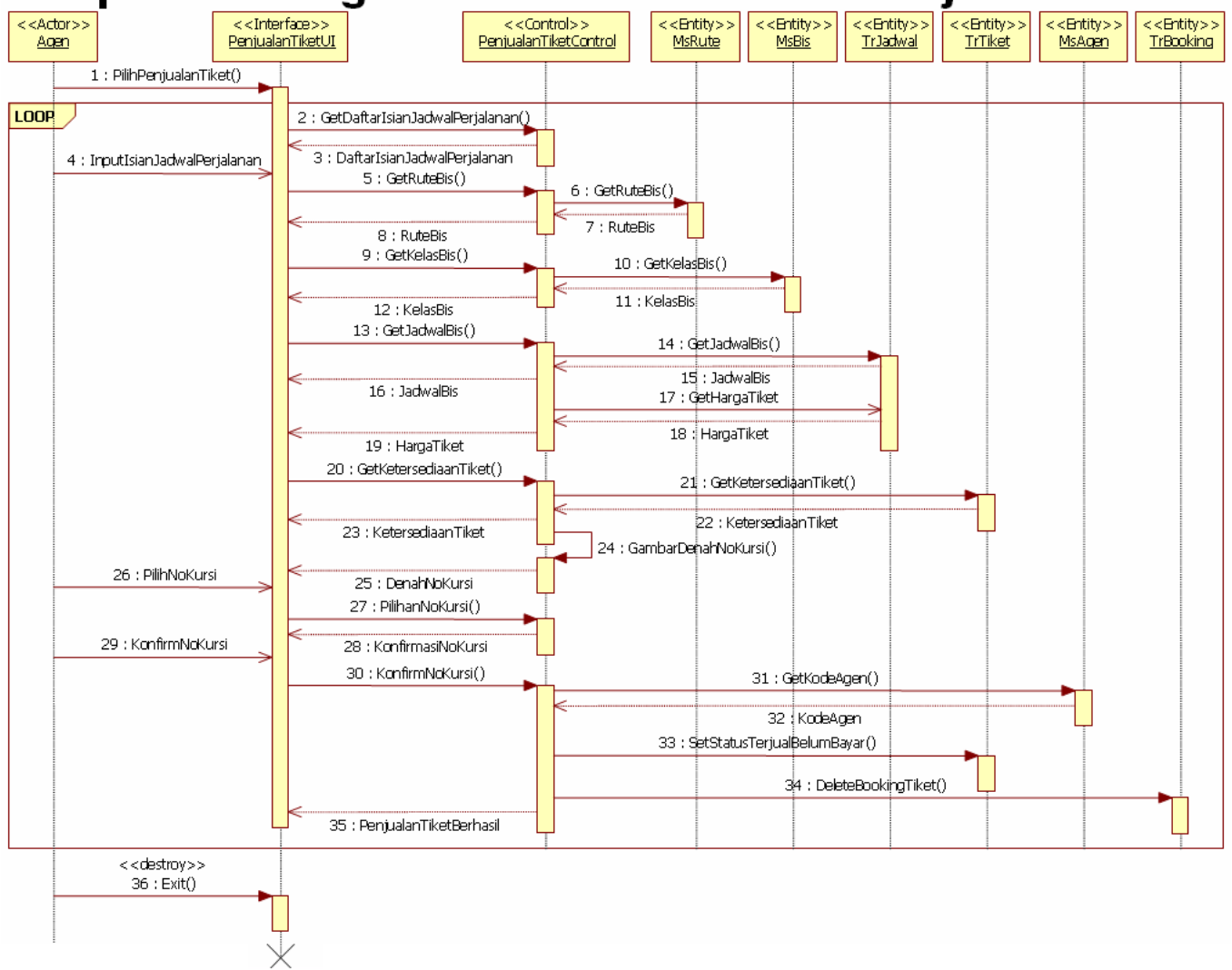

Gambar 7 Sequence diagram untuk use case penjualan tiket 
Sequence Diagram Untuk Use Case Bayar Tiket

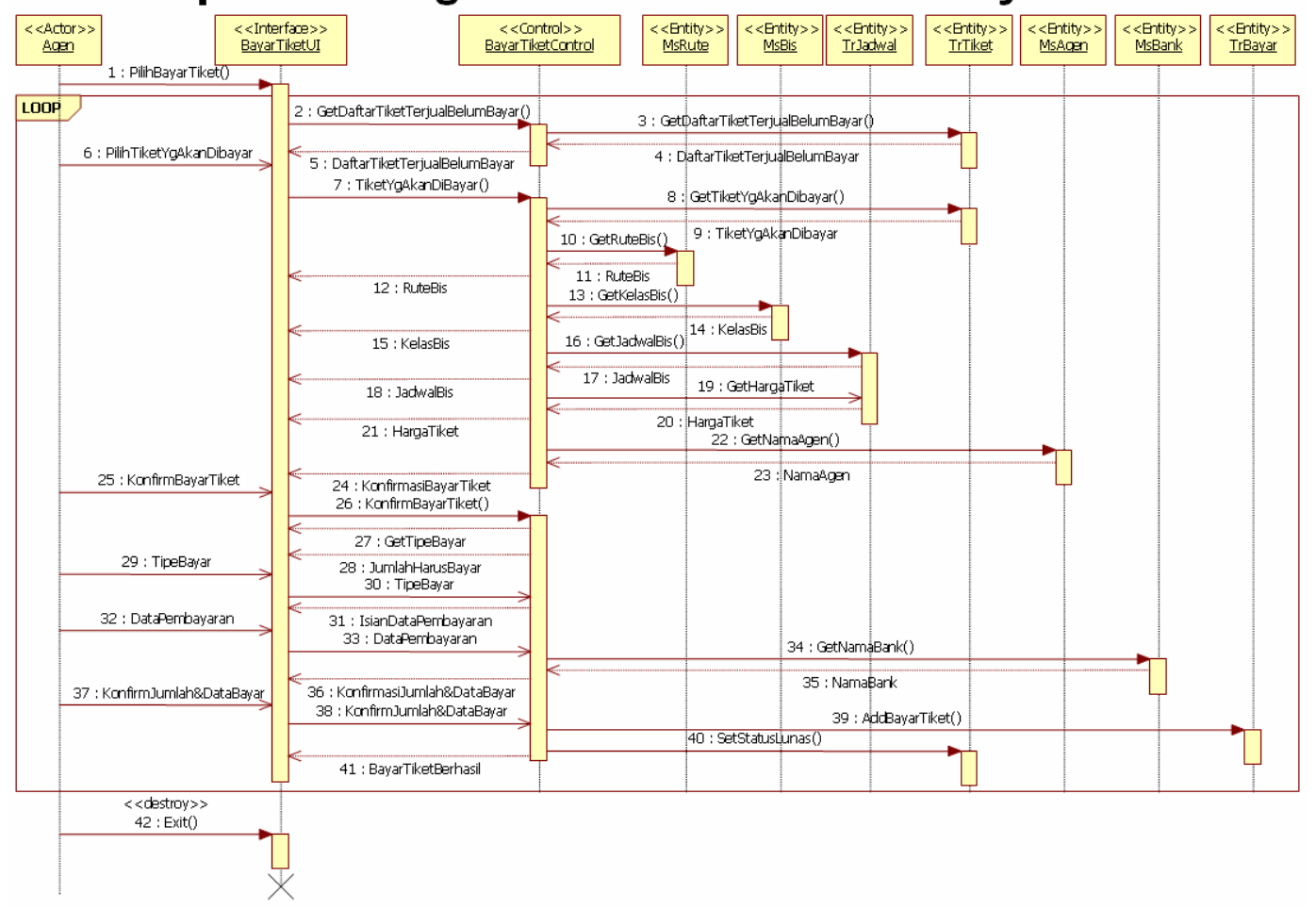

Gambar 8 Sequence diagram untuk use case bayar tiket

\section{Sequence Diagram Untuk Use Case Cetak Tiket}

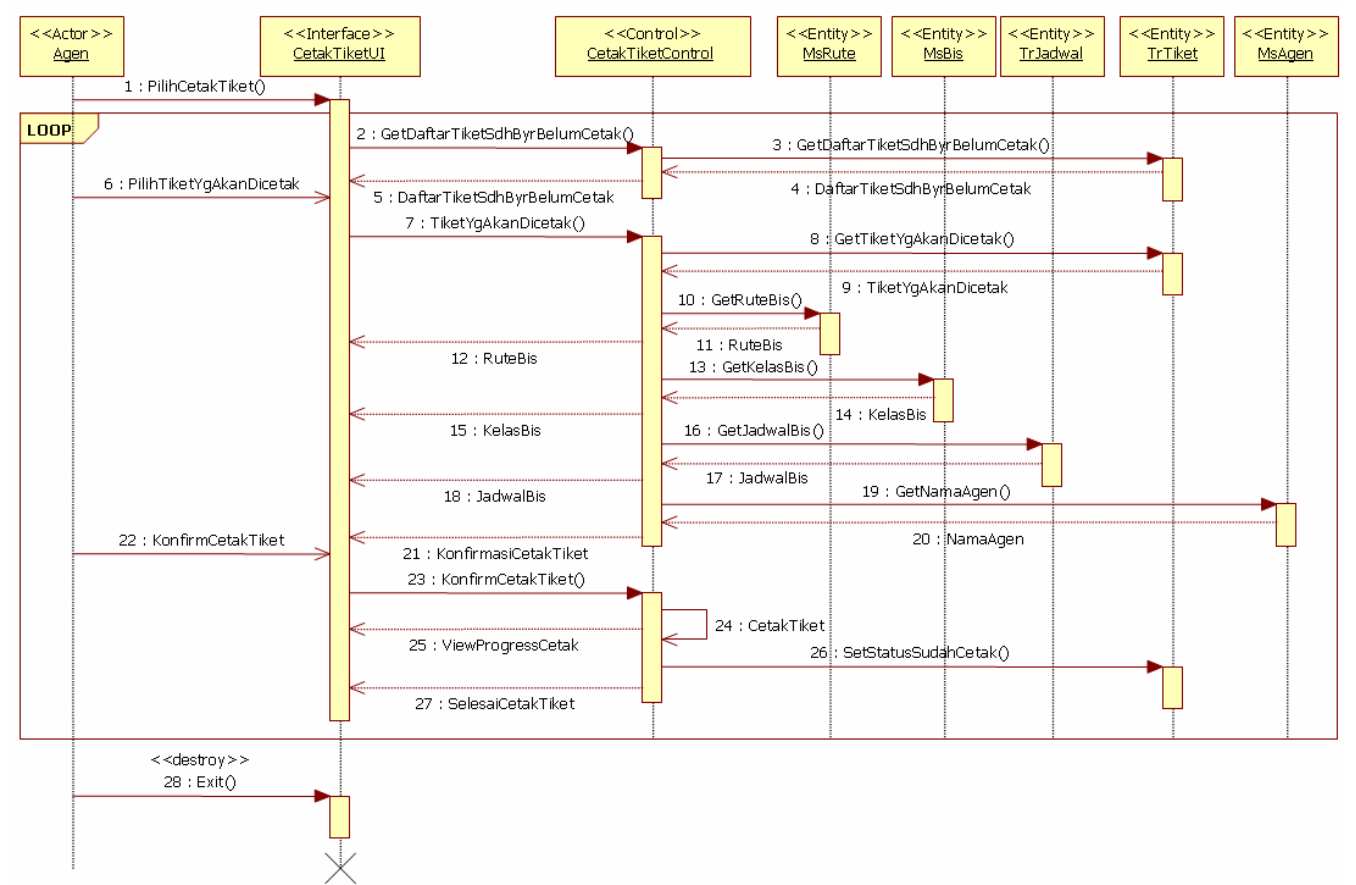

Gambar 9 Sequence diagram untuk use case cetak tiket 


\section{Sequence Diagram Untuk Use Case Sinkronisasi Data}

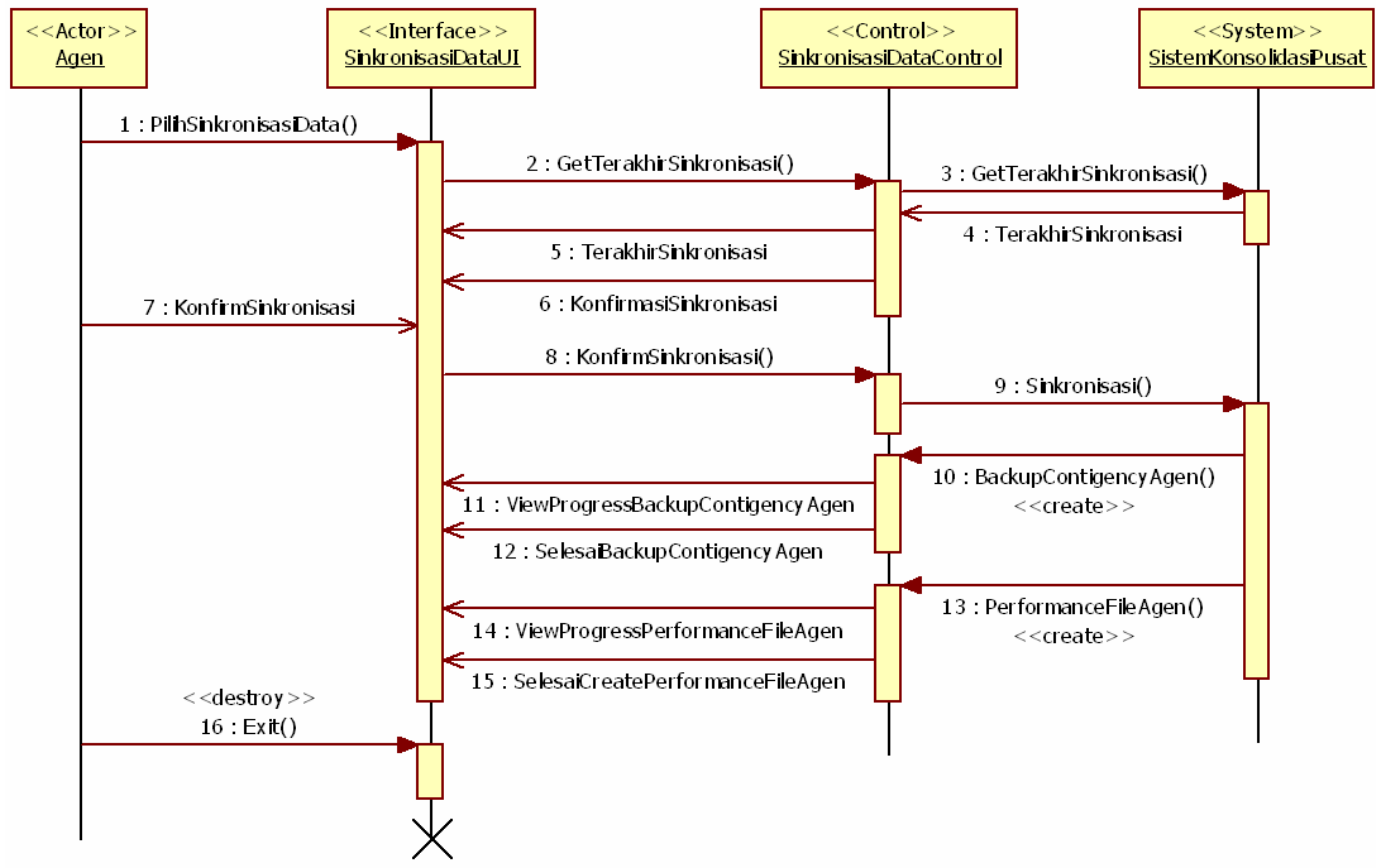

Gambar 10 Sequence diagram untuk use case sinkronisasi data

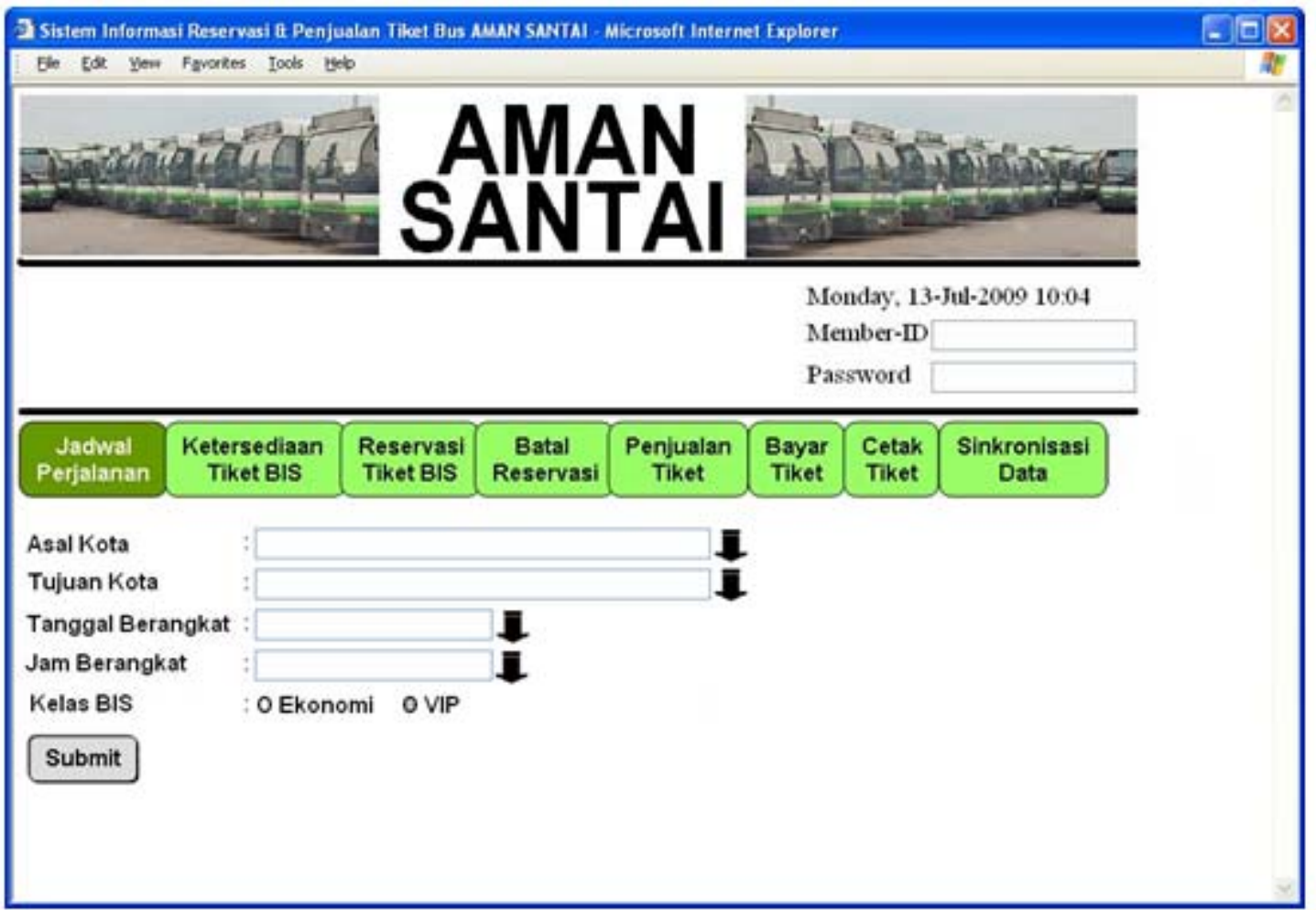

Gambar 11 Form isian pencarian jadwal perjalanan 
Tiket Bus

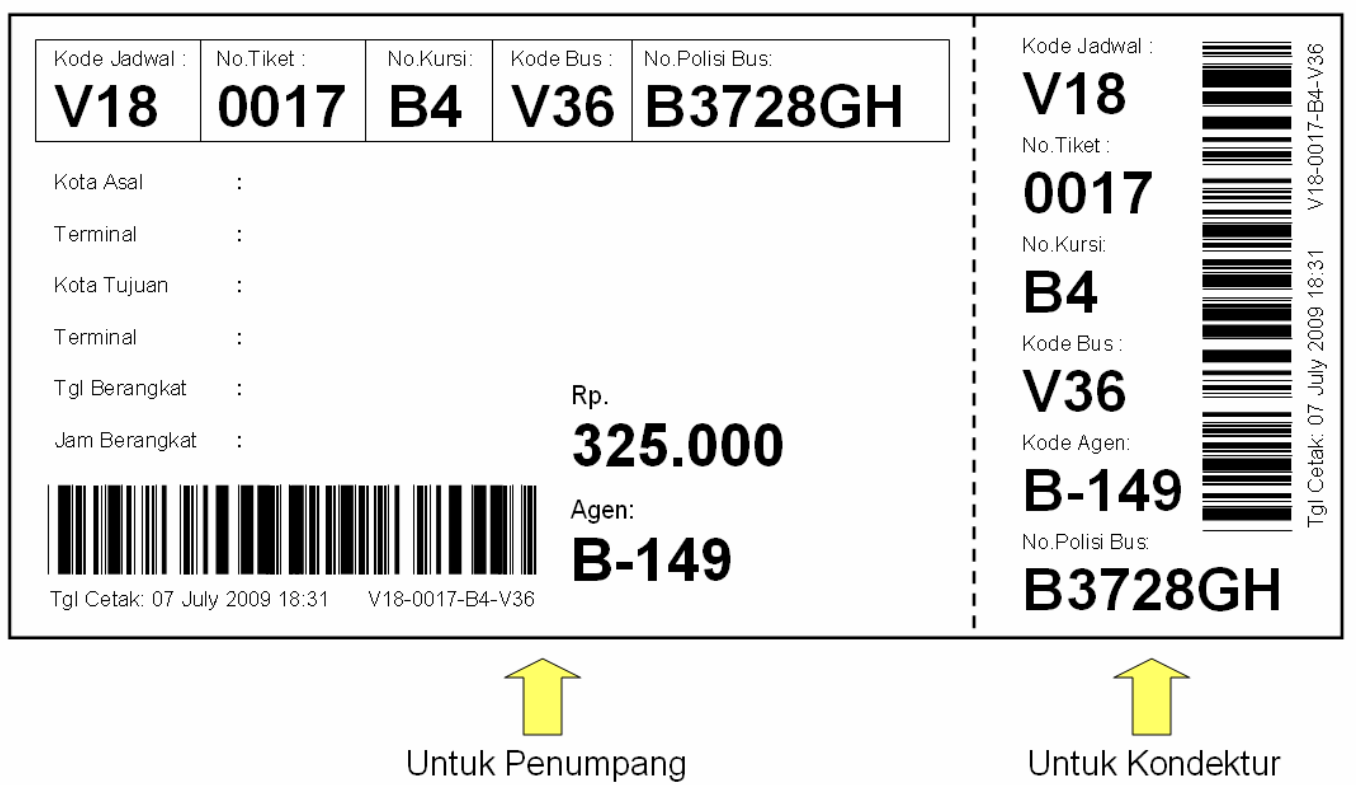

Gambar 12 Tiket bus

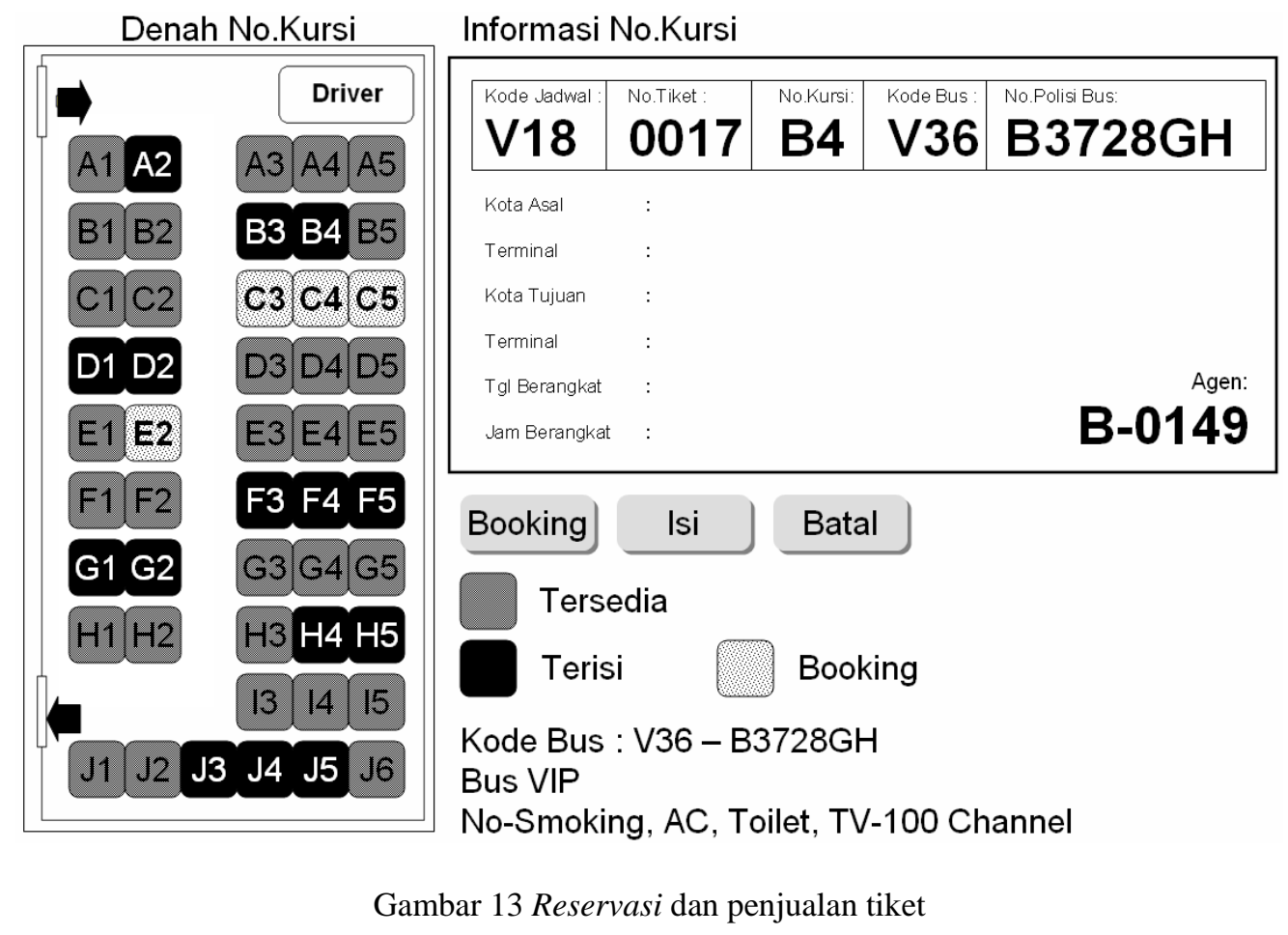

\section{PENUTUP}

Dengan adanya model perancangan sistem informasi pemesanan tiket antar kota antar propinsi diharapkan suatu sistem informasi yang mudah untuk dibangun dan diterapkan dapat dirancang sehingga dapat mempermudah pemesanan tiket khususnya pemesanan tiket di cabang. Dengan 
dibuatnya suatu model perancangan sistem informasi pemesanan tiket antar kota antar propinsi ini, diharapkan akan dikembangkan model perancangan sistem informasi transportasi khusus di cabang secara keseluruhan dan pada akhirnya akan dikembangkan suatu model perancangan sistem informasi yang terpadu antar cabang dengan kantor pusat.

\section{DAFTAR PUSTAKA}

Republik Indonesia. (2009). Undang - undang No. 22 tahun 2009, Lalu Lintas dan Angkutan Jalan. Jakarta: Republik Indonesia.

Turban, Efraim, Rainer, R. Kelly Jr., Potter, Richard E. (2003). Introduction to Information Technology (3rd edition). Canada: John Wiley dan Sons. 